\title{
Germination and morphological characterization of the fruits, seeds, and seedlings of Pilosocereus gounellei ${ }^{1}$
}

\author{
HAYNNA FERNANDES ABUD ${ }^{2,6}$, NAYARA ROBERTO GONÇALVES ${ }^{3}$, \\ MAGNUM DE SOUSA PEREIRA ${ }^{4}$, DIEGO DE SOUSA PEREIRA ${ }^{3}$, \\ RODRIGO DE GÓES ESPERON REIS ${ }^{3}$ and ANTONIO MARCOS ESMERALDO BEZERRA 5 .
}

(received: September 15, 2010; accepted: December 22, 2011)

\begin{abstract}
Germination and morphological characterization of the fruits, seeds, and seedlings of Pilosocereus gounellei). The present work examined the germination and morphology of the fruits and seeds of the cactus Pilosocereus gounellei (xique-xique) and describeb the different stages of seedling growth. Germination tests examined the effects of combinations of two illumination regimes (a 12 hour photoperiod and total darkness) and three temperature regimes $\left(25,30\right.$, and $\left.20-30{ }^{\circ} \mathrm{C}\right)$ on the seeds of this species. Germination counts were made daily until the $16^{\text {th }}$ day after sowing and the germination percentage and velocity index, and average germination time were evaluated. Descriptions of seed morphology considered both their external and internal aspects. The processes of germination and seedling growth were evaluated during 150 days and eight developmental stages were identified based on morphological changes. The fruits of the xique-xique cactus are $40.67 \pm 4.40 \mathrm{~mm}$ long and $48.09 \pm 3.23 \mathrm{~mm}$ in diameter, weigh $53.85 \pm 10.03 \mathrm{~g}$, and contain $3713 \pm 689.50$ seeds. Alternating temperatures of $20-30{ }^{\circ} \mathrm{C}$ together with a photoperiod of 12 hours of light resulted in the highest seed germination rate. The seeds are positively photoblastic and germination is epigeal and fanerocotyledonary. Seedling growth is slow, but at 150 days after sowing the plants had developed epicotyls, large numbers of thorns, and the whole plant averaged $59.56 \mathrm{~mm}$ in height.
\end{abstract}

Key words - Cactaceae, morphology, seedling growth

\section{INTRODUCTION}

Cactaceae is one of the most interesting families among the Angiosperms as its species have evolved a series of adaptations to extremely dry environments that allow perennial growth (Rojas-Aréchiga \& VásquezYanes 2000). There are about 40 genera and 200 species of cacti in Brazil distributed throughout diverse ecosystems, especially in the northeastern region of the country in the Caatinga dryland biome (Souza \& Lorenzi 2005), with the xique-xique cactus (Pilosocereus gounellei (F.A.C.Weber) Byles \& G.D. Rowley.) being very characteristic of that area (Cavalcanti \& Resende 2006).

Seeds represent the principal form of dissemination for most plant species and are largely responsible for the preservation of biodiversity (Marcos Filho 2005). Seed

1. Part of the masters' dissertation of the first author, Programa de Pós-Graduação em Agronomia, Universidade Federal do Ceará, CE, Brazil

2. Universidade Federal de Viçosa, Avenida P.H. Rolfs s/n,:36570-000 Viçosa, MG, Brazil

3. Universidade Federal de Lavras, Caixa Postal 3037, 37200-000 Lavras, MG, Brazil

4. Universidade Federal do Ceará, Campus do Pici s/n, 60455-760 Fortaleza, CE, Brazil

5. Universidade Federal do Ceará, Campus do Pici s/n, 60455-760, Fortaleza, CE, Brazil

6. Corresponding author: hfabud@gmail.com germination is influenced by temperature regimes - which act directly on the velocity of water absorption and on biochemical reactions, thus exercising a determinant role in germination processes. Favorable growth temperatures for most cactus species are between 15 and $35^{\circ} \mathrm{C}$, and optimal germination is normally near $25^{\circ} \mathrm{C}$ (RojasAréchiga \& Vásquez-Yanes 2000).

Details concerning cactus seed germination and morphological characterizations of their fruits, seeds, and seedlings are rather rare in the literature, especially those focusing on native Brazilian species. Nonetheless, it is possible to find published information about seed germination and seedling development for Cephalocereus fluminensis (Salles 1987), Stenocereus thurberi (Nolasco et al. 1997), Stenocereus stellatus (Rojas-Aréchiga 2001), Stenocereus queretaroensis (Barrera \& Nobel 2003), Melocactus bahiensis (Lone et al. 2007), Trichocereus terscheckii (Ortega-Baes \& Rojas-Arechiga 2007), Hylocereus setaceus (Simão et al. 2007), Denmoza rhodacantha (Méndez 2007), Hylocereus undatus (Andrade et al. 2008), Mammillaria huitzilopochtli (Flores-Martínez et al. 2008), Cereus fernambucensis, Coleocephalocereus fluminensis, Pilosocereus arrabidae, Pilosocereus ulei (Almeida et al. 2009), and Pilosocereus pachycladus (Abud et al. 2010).

Knowledge of the morphological characteristics of seeds is important to activities designed to maintain 
biodiversity and for understanding and describing germinative processes (Oliveira et al. 2006). Studies of the morphological aspects of germination not only contribute to the assisted propagation of those species, but can aid in the classification of germination processes in relation to the position of the cotyledons and in interpreting and standardizing germination tests, and thus contributing to our understanding of their morpho-anatomical nature. Beltrati (1995) noted that studies of the characteristics of seeds and seedlings can provide information necessary to identify species in the field and among seed samples. Additionally, the biometric characterization of the fruits and seeds provide information that can be used to differentiate between species of the same genus (Cruz et al. 2001).

In light of the general lack of detailed information about germination and seedling development in native cactus species from the Caatinga dryland region of northeastern Brazil, the present study evaluated the seed germination behavior of $P$. gounellei under different conditions of illumination and temperature and describes the morphology of the fruits and seeds and the different growth phases of this species.

\section{MATERIAL AND METHODS}

The seeds of the cactus $P$. gounellei utilized in the present experiments were obtained from mature fruits harvested from plants growing in the Vale do Curu Experimental Farm at the Federal University of Ceará (UFC), which is located in Pentecoste, Ceará State (CE), Brazil. After harvesting, the fruits were stored in plastic sacks for transportation to the Seed Analysis Laboratory of the UFC in Fortaleza, CE. The seeds were extracted by opening the fruits and removing the pulp, which was then macerated and passed through a sieve and washed in running water. The seeds were subsequently allowed to dry in the shade for 48 hours. The moisture content of the seeds and their average weights were determined using the methodologies described by the Rules for Seed Analysis (Regras para Análises de Sementes, Brasil 2009).

Ten fruits were used for biometric determinations, considering the length as the region between the base and the apex and the diameter in the median region of the fruits; digital calipers were used (precision $0.01 \mathrm{~mm}$ ). The descriptive statistics described the averages, confidence intervals, standard deviations, and coefficients of variation of the biometric characteristics. The morphological descriptions of the fruits considered external aspects such as type, shape, epicarp color, fruit weight, number of seeds per fruit and seed weight, following Barroso et al. (1999).

The germination tests compared two illumination regimes (a 12 hour photoperiod and complete darkness) and three different temperatures regimes $(25 ; 30$; and alternating
20-30 ${ }^{\circ} \mathrm{C}$ ) disposed in a factorial scheme $2 \times 3$, in a completely randomized design with four repetitions. The seeds were sown in $14 \mathrm{~cm}$ diameter Petri dishes lined with a double layer of filter paper humidified with distilled water ( 2.5 times the weight of the dry paper). A seed was considered to have germinated if its radicule emerged 1 millimeter or longer. In order to determine the effects of temperature and light on seed germination, daily counts were made until the 16th day after sowing to evaluate the following variables: germination percentage - determined by counting the numbers of normal seedlings of each experimental lot and expressing the results as percentages; germination speed index - according to the methodology described by Maguire (1962); and mean time of germination -according to the equation proposed by Labouriau, 1983). Seeds maintained in darkness were examined under a green safety light. The data were submitted to analysis of variance and the averages were compared using the Tukey test, considering a 5\% confidence level.

Fifty $P$. gounellei seeds chosen unsystematically were used in the morphological descriptions, evaluating both external (type, shape, testa structure, and color) and internal aspects (embryo and reserve tissues), following Barroso et al. (1999) and Beltrati (1995). Internal morphological characterizations used seeds that had been soaked in distilled water for 24 hours to soften and hydrate them. After imbibition, the seeds were cut along their longitudinal plane and examined using a INALH - MLS 250 dissecting microscope.

Descriptions and illustrations of the external morphology of seedlings and plantlets were performed by sowing 200 seeds in polyethylene trays containing vermiculite and humus $(1: 1 \mathrm{v} / \mathrm{v})$ that were then maintained under greenhouse conditions $\left(50 \%\right.$ shading, average temperature of $29.6{ }^{\circ} \mathrm{C}$, and $60 \%$ relative humidity) with intermittent watering. The final stages of growth were evaluated in specimens that had been transplanted (70 days after sowing) into $12 \times 15 \mathrm{~cm}$ polyethylene sacks containing sand and humus $(1: 1 \mathrm{v} / \mathrm{v})$. The processes of germination and plant growth were followed for 150 days; eight stages of development were identified based on morphological differences. Only the most vigorous plants were selected for evaluation - being those that had healthy root systems, epicotyls, and hypocotyls according to Barroso et al. (1999) and Beltrati (1995). The external morphological aspects of the seeds, the germination process, and plant growth were illustrated manually.

\section{RESULTS AND DISCUSSION}

One thousand $P$. gounellei seeds weighed approximately $1.3 \mathrm{~g}$, so that $1 \mathrm{~g}$ contained approximately 735 seeds. The water content of the seed lot tested was $10 \%$. Marcos Filho (2005) noted that one of the principal factors determining seed weight is their water content, which can vary according to local harvesting conditions, their age, and their degree of maturity. 
Germination percentages varied as a function of incubation temperature. The best results in terms of percentage and germination speed index (table 1) were observed under an alternating temperature regime of $20-30{ }^{\circ} \mathrm{C}$ with a $12: 12$ light/dark cycle, yielding values of $89 \%$ and 8.3 respectively. It can be seen in table 1 that the lowest values of germination percentage and velocity were obtained at $25{ }^{\circ} \mathrm{C}(29 \%$ and 2.1 respectively). Rojas-Aréchiga \& VásquezYanes (2000) reported that cactus seed germination responded favorably to temperatures between 15 and $35^{\circ} \mathrm{C}$, with a constant temperature of $25^{\circ} \mathrm{C}$ being optimal for most species. It can also be seen in table 1 that there were no significant differences in germination percentages between temperatures regimes of $25^{\circ} \mathrm{C}$ $(29 \%)$ and $30{ }^{\circ} \mathrm{C}(35 \%)$. Additionally, it can be seen that germination in $P$. gounellei was prolonged, indicating that these environmental temperatures affected metabolic reactions and enzyme activations involved in the germination process. Optimal temperatures allow maximum germination in the shortest space of time, while higher or lower temperatures can result in considerable reductions in germination speed.

Table 1. Average germination percentages, germination speed indexes (GSI) and mean germination times (MTG) of Pilosocereus gounellei (xique-xique) exposed to three different temperature regimes and a 12 hour daily photoperiod.

\begin{tabular}{lccl}
\hline Temperatures & Germination (\%) & GSI & MTG \\
\hline $25^{\circ} \mathrm{C}$ & $29 \mathrm{~B}$ & $2.1 \mathrm{C}$ & $7.7 \mathrm{~A}$ \\
$30^{\circ} \mathrm{C}$ & $35 \mathrm{~B}$ & $3.8 \mathrm{~B}$ & $5.0 \mathrm{~B}$ \\
$20-30{ }^{\circ} \mathrm{C}$ & $89 \mathrm{~A}$ & $8.3 \mathrm{~A}$ & $5.7 \mathrm{~B}$ \\
$\mathrm{LSD}$ & 9.64 & 1.02 & 1.08 \\
$\mathrm{CV}(\%)$ & 21.09 & 24.11 & 8.97 \\
\hline
\end{tabular}

Averages followed by the same letter not differ statistically among themselves, by the Tukey test at a $5 \%$ probability level.
Recent studies have demonstrated that lightstimulates germination in a number of cactus species, indicating that they are positively photoblastic (Rojas-Aréchiga \& Vásquez-Yanes 2000; Ortega-Baes \& Rojas-Aréchiga 2007). When the seeds of $P$. gounellei were incubated in total darkness there was a total absence of germination at all of the temperatures evaluated - indicating that this species is positively photoblastic. This suggests that under dark conditions there are insufficient minimum concentrations of cytochrome in its active form to initiate germination processes involving hormone synthesis and gene transcription (Marcos Filho 2005). These results corroborated those of Benítez-Rodrígues et al. (2004) who studied the effects of light on the germination of four species of the genus Mammillaria and determined that their seeds were all positively photoblastic. Abud et al. (2010) reported similar results with Pilosocereus pachycladus, whose seeds demonstrated positive photoblastic behavior and no germination in the absence of light.

$P$. gounellei seeds demonstrated maximum germinability at $30^{\circ} \mathrm{C}$ five days after sowing, although this germinability was not statistically different from that observed under alternating temperatures of $20-30{ }^{\circ} \mathrm{C}$ at 5.7 days (table 1). As there was no germination at all in the dark, our germination analyses were based on the results attained with seeds exposed to photoperiods of 12 hours.

In terms of the morphological descriptions of the fruits, it was observed that they are fleshy capsules with a glabrous green epicarp (figure 1A) during maturation; upon attaining physiological maturity the epicarp takes on a deep purple color (figure 1B). The fruits are laterally dehiscent and are classified as polyspermic, with a thick and succulent pericarp; the pulp is mucilaginous and dark pink/purple (figure 1C). This description is in agreement with the taxonomic study undertaken by Rocha \& Agra (2002) of representatives of the family Cactaceae.

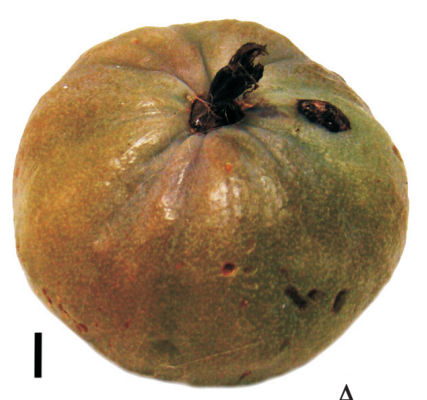

A
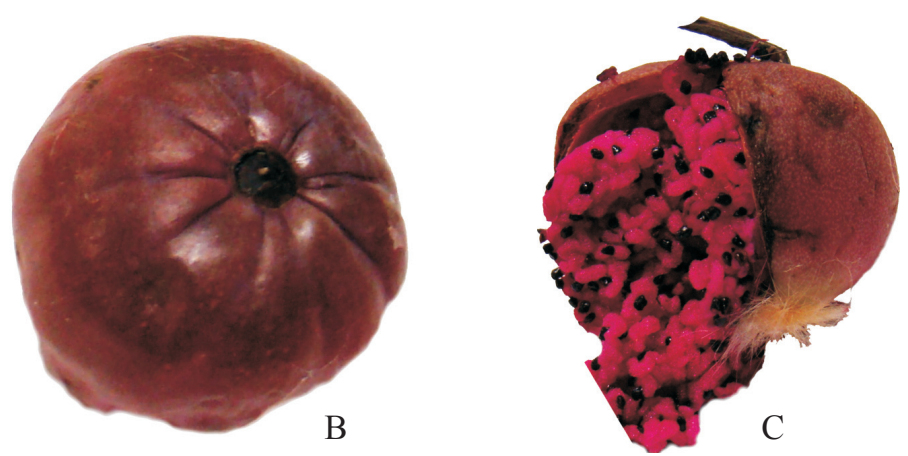

Figure 1. External views of the ripe fruit of Pilosocereus gounellei (xique-xique), immature (A), mature (B), and internal aspect $(\mathrm{C})$. Bar $=10 \mathrm{~mm}$. 
Table 2 presents the descriptive statistics of the morphology and biometry of $P$. gounellei fruits. The fruits of this xique-xique cactus are $40.67 \pm 4.40 \mathrm{~mm}$ long and $48.09 \pm 3.23 \mathrm{~mm}$ in diameter, weigh $53.85 \pm$ $10.03 \mathrm{~g}$, and contain $3,713 \pm 689.50$ black seeds dispersed within a dark pink/purple pulp. The weights of the fruits and the seeds and the numbers of seeds per fruit vary greatly, as can be seen by their respective coefficients of variation. Rojas-Aréchiga \& VázquezYanes (2000) noted that the numbers of seeds per fruit can vary considerably, depending on cactus the species involved, but that there were also large differences in the numbers of seeds produced per fruit even within the same species - depending on the age of the plant and its size, among other factors. In a similar study, Abud et al. (2010) reported that the fruits of Pilosocereus pachycladus were polyspermic and contained approximately $3786.10 \pm 489.42$ seeds per fruit.

Table 2. Characterization of fruits of Pilosocereus gounellei (xique-xique) in terms of their weight, length, diameter, numbers of seeds, and seed weight.

\begin{tabular}{|c|c|c|c|}
\hline Characteristics & Average & $\begin{array}{l}\text { Standard } \\
\text { error }\end{array}$ & $\begin{array}{l}\mathrm{CI}^{1} \\
(\%)\end{array}$ \\
\hline Fruit weight (g) & $53.85 \pm 10.03$ & 16.17 & 30.04 \\
\hline Length (mm) & $40.67 \pm \quad 4.40$ & 7.11 & 17.47 \\
\hline Diameter (mm) & $48.09 \pm 3.23$ & 5.20 & 10.82 \\
\hline № of seeds & $3713 \pm 689.50$ & 1112.44 & 29.96 \\
\hline Seed weight (g) & $4.05 \pm 0.79$ & 1.28 & 31.60 \\
\hline
\end{tabular}

${ }^{1}$ Confidence Interval (95\%), obtained by: $\bar{x} \pm t_{\alpha / 2} \frac{S}{\sqrt{n}}$

In terms of the morphology of the seeds of $P$. gounellei, they were found to be estenospermic, exalbuminous, with a smooth, shiny, black tegument, a slightly irregular shape (figure 2A), and were exotestal and bitegumented. The embryo was easily observed in the seeds after imbibition, being peripheral, white, cylindrical and large, and occupying almost the entire inner volume of the seed; the cotyledon reserve tissue was whitish and consistently firm (figure 2A).

Cactus seeds come in many shapes, colors, forms, and sizes. Rojas-Aréchiga \& Vásquez-Yanes (2000) reported that cactus seeds could be reniform, globular, oval, or pyriform, and could be black, brown, reddish, or other colors.

Figure 2 demonstrates eight stages in the growth of $P$. gounellei during the first 150 days after sowing. The seeds of the xique-xique cactus had an average length of $1.77 \mathrm{~mm}$ (figure 2A). Approximately 5 days after sowing the radicule was observed to protrude $1.95 \mathrm{~mm}$ from the seed (figure 2B). A similar study of Pilosocereus pachycladus (facheiro), a species within the same family as $P$. gounellei and demonstrating similar developmental phases, found that radicule protrusion $(1.55 \mathrm{~mm})$ occurred approximately 96 hours after sowing (Abud et al. 2010).

The radicule of $P$. gounellei grew rather rapidly, and seven days after sowing had attained an average length of $2.36 \mathrm{~mm}$ (figure 2C). Hypocotyl development occurred later, and approximately 11 days after sowing it had reached $4.30 \mathrm{~mm}$ in length (figure 2D). By this time the seedlings had completely liberated themselves from the tegument as the cotyledons progressively opened (figure 2D). Twenty-one days after sowing the hypocotyl was completely erect and approximately $12.07 \mathrm{~mm}$ long (figure 2E). Epicotyl development was quite slow, only occurring approximately 52 days after sowing, when spines could be observed between the cotyledons, the seedling measured $21.45 \mathrm{~mm}$ from root to stem apex at this time (figure 2F). At 90 days after sowing, the epicotyl had grown significantly $(38.61 \mathrm{~mm})$ and had large numbers of spines (figure 2G). After this date, morphological modifications were restricted to the growth of the epicotyl, and at 150 days the plants had total average lengths of $59.56 \mathrm{~mm}$ from the roots to the stem apex (figure 2H). A similar study followed the developmental stages of Cephalocereus fluminensis plantlets from germination until the initiation of epicotyl development 90 days after sowing (Salles 1987). It was also observed that the epicotyl of Pilosocereus pachycladus was growing notably at 150 days after sowing (being $94.31 \mathrm{~mm}$ long from the roots to the stem apex) and had large numbers of spines (Abud et al. 2010).

\section{REFERENCES}

Abud HF, Gonçalves NR, Reis RGE, Pereira DS, Bezerra AME. 2010. Germinação e expressão morfológica de frutos, sementes e plântulas de Pilosocereus pachycladus Ritter. Revista Ciência Agronômica 41:468-474.

Andrade RA, Oliveira IVM, Silva MTH, Martins ABG. 2008. Germinação de Pitaya em diferentes substratos. Revista Caatinga 21:71-75.

Almeida THM, Andrade ACS, Lopes HM. 2009. Brazilian cacti seed germination under different temperature and substrate conditions. Seed Science and Technology 37:474-479.

Barrera ED, Nobel PS. 2003. Physiological ecology of seed germination for the columnar cactus Stenocereus queretaroensis. Journal of Arid Enviroments 53:297-306. 


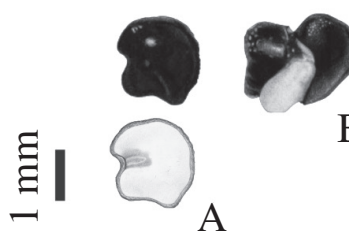

$\mathrm{B}$

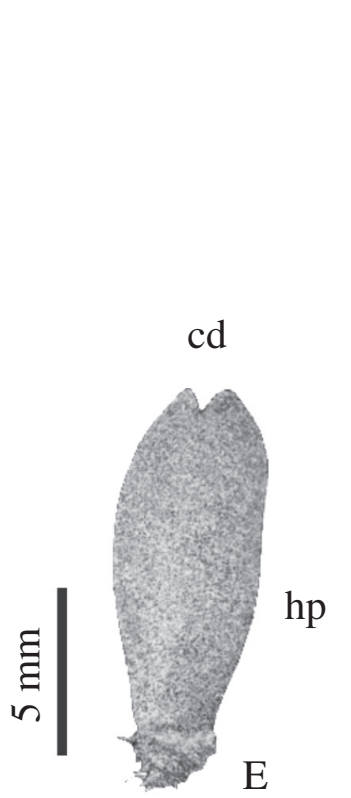

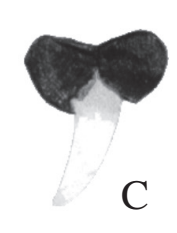
$\mathrm{hr}$

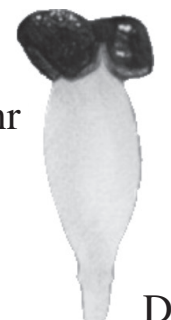

$\mathrm{D}$

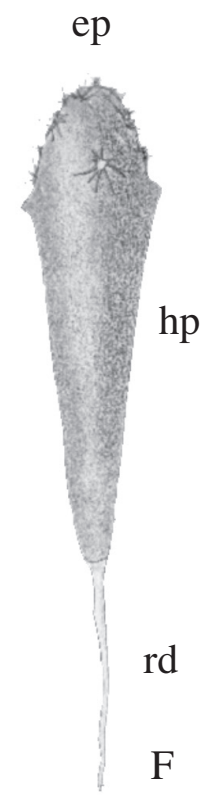

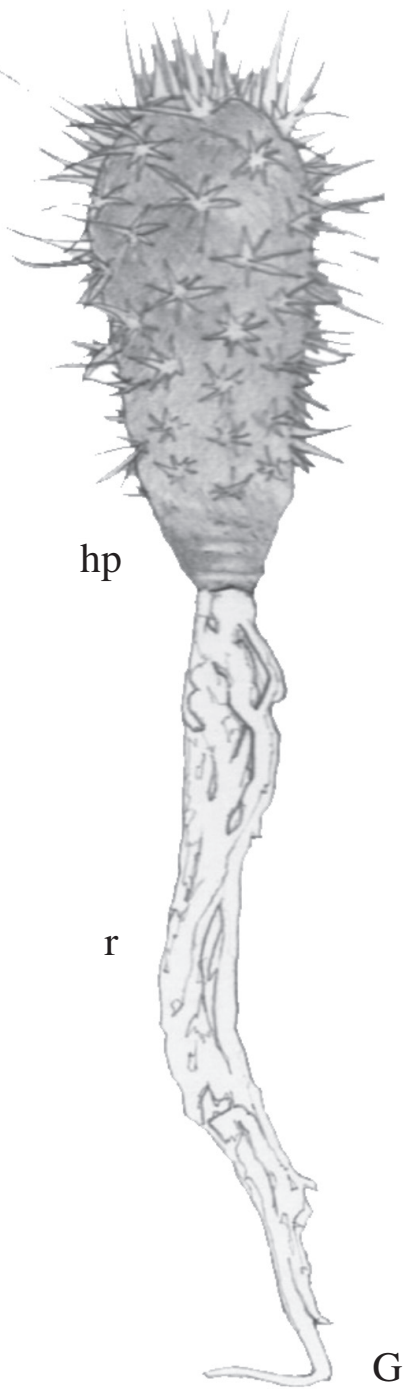

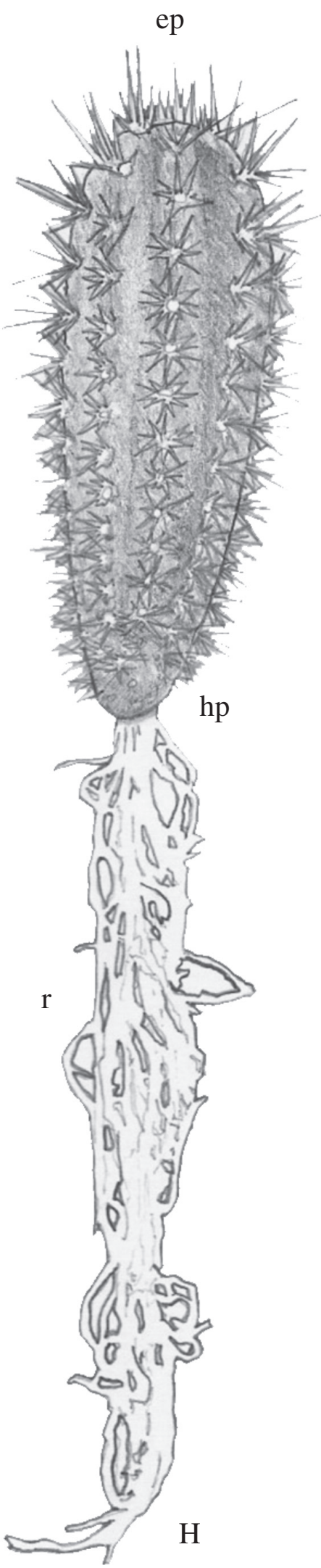

Figure 2. Morphological aspects of the seed (A) and the different growth stages (B-H) of Pilosocereus gounellei (xique-xique) up to 150 days after sowing $(\mathrm{hr}=$ hypocotyl-radicule axis; $\mathrm{hp}=$ hypocotyl; $\mathrm{cd}=$ cotyledons; $\mathrm{ep}=$ epicotyls; $\mathrm{rd}=$ radicule; $\mathrm{r}$-root $)$. 
Barroso GM, Morim MP, Peixoto AL, Ichaso CLF. 1999. Frutos e sementes: morfologia aplicada à sistemática de dicotiledôneas. Universidade Federal de Viçosa, Viçosa.

Beltrati CM. 1995. Morfologia e anatomia de sementes In Curso de Pós- graduação em Ciências Biológicas, área de Biologia Vegetal. Universidade Estadual Paulista, Rio Claro.

Benítez-Rodríguez JL, Orozco-Segovia A, Rojas-Aréchiga M. 2004. Light effects on seed germination of four Mammillaria species from the Tehuacán-Cuicatlán Valley, Central Mexico. The Southwestern Naturalist 49:11-17.

Braga R. 1976. Plantas do Nordeste, especialmente do Ceará. 3a ed. Escola Superior de Agricultura de Mossoró, Mossoró.

Brasil, Ministério da Agricultura e Reforma Agrária. 2009. Regras para análises de sementes. SNDA/DNDV/CLAV, Brasília.

Cavalcanti NB, Resende GM. 2006. Consumo de mandacaru (Cereus jamacaru P. DC.) por caprinos na época seca do semi-árido de Pernambuco. Revista Caatinga 19: 402-408.

Cruz DE, Martins FO, Carvalho JEU. 2001. Biometria de frutos e sementes e germinação de jatobá-curuba (Hymenea intermedia Ducke, Leguminosae, Caesalpinoideae). Revista Brasileira de Botânica 24:161-165.

Flores-Martínez A, Manzareno GI, Rojas-Aréchiga M, Mandujano MC, Golubov J. 2008. Seed age germination responses and seedling survival of an endangered cactus that inhabits cliffs. Natural Areas Journal 28:51-57.

Labouriau LG. 1983. A germinação das sementes. Secretaria Geral da OEA, Washington D.C.

Lone AB, Takahashi LSA, Faria RT, Unemoto LK. 2007. Germinação de Melocactus bahiensis (Cactaceae) em diferentes substratos e temperaturas. Scientia Agrária 8:365-369.

Loza-Cornejo S, Terrazas T, Lopez-Mata L, Trejo C. 2003. Características morfo-anatómicas y metabolismo fotosintético en plántulas de Stenocereus queretaroensis (Cactaceae): su significado adaptativo. Interciência 28:83-89.
Marcos Filho J. 2005. Fisiologia de sementes de plantas cultivadas. Fundação de Estudos Agrários Luiz de Queiroz, Piracicaba.

Maguire JD. 1962 Speed of germination-aid in selection and evaluation for seedling emergence and vigor. Crop Science 2:176-177.

Méndez E. 2007. Germination of Demonza rhodacantha (Salm-Dyck) Britton \& Rose (Cactaceae). Journal of Arid Environments 68:678-682.

Nolasco H, Veja-Villasante F, Diaz-Rondero A. 1997. Seed germination of Stenocereus thurberi (Cactaceae) under different solar irradiation levels. Journal of Arid Environments 36:123-132.

Oliveira AKM, Schleder ED, Favero S. 2006. Caracterização morfológica, viabilidade e vigor de sementes de Tabebuia aurea (Silva Manso) Benth. \& Hook. F. ex. S. Moore. Revista Árvore 30:25-32.

Ortega-Baes P, Rojas-Aréchiga M. 2007. Seed germination of Tricocereus terscheckii (Cactaceae): Light, temperature and gibberellic acid effects. Journal of Arid Environments 69:169-176.

Rocha EA, Agra MF. 2002. Flora do Pico do Jabre, Paraíba, Brasil: Cactaceae Juss. Acta Botanica Brasilica 16: 15-21.

Rojas-Aréchiga M, Casas A, Vázquez-Yanes C. 2001. Seed germination of wild and cultivated Stenocereus stellatus (Cactaceae) from the Tehuacán-Cuicatlán Valley, Central México. Journal of Arid Environments 49:279-287.

Rojas-Aréchiga M, Vásquez-Yanes C. 2000. Cactus seed germination: a review. Journal of Arid Environments 44:85-104.

Salles HG. 1987. Expressão morfológica de sementes e plântulas I. Cephalocereus fluminensis (Miq) Britton e Rose (Cactaceae). Revista Brasileira de Sementes 9: 73-81.

Simão E, Socolowski F, Takaki M. 2007. The epiphytic Cactaceae Hylocereus setaceus (Salm-Dick ex DC.) ralf bauer seed germination is controlled by light and temperature. Brazilian Archives of Biology and Technology 50:655-662.

Souza VC, Lorenzi H. 2005. Botânica sistemática: guia ilustrado para identificação das famílias de Angiospermas da flora brasileira. Instituto Plantarum, Nova Odessa. 